\title{
ВЛИЯНИЕ СТРУКТУРЫ ХИРУРГИЧЕСКИХ ИНСТРУМЕНТОВ НА ОПЕРИРУЕМЫЕ ТКАНИ ЖИВОТНЫХ
}

\author{
N.V. Sakhno, Yu.A. Vatnikov,A.V. Shadskaya, \\ S.M. Kuleshov, E.V. Kulikov, E.A. Krotova, \\ V.I. Semenova
}

\section{THE INFLUENCE OF THE STRUCTURE OF SURGICAL INSTRUMENTS ON OPERATED TISSUES OF ANIMALS'}

Сахно Николай Владимирович - д-р ветеринар. наук, проф. каф. эпизоотологии и терапии Орловского государственного аграрного университета им. Н.В. Парахина, г. Орел.

E-mail: sahnoorelsau@mail.ru

Ватников Юрий Анатольевич - д-р ветеринар. наук, проф., директор Департамента ветеринарной медицины Российского университета дружбы народов, г. Москва. E-mail: vatnikov@yandex.ru

Шадская Анастасия Викторовна - канд. ветеринар. наук, доц. каф. эпизоотологии и терапии Орловского государственного аграрного университета им. Н.В. Парахина, г. Орел.

E-mail: eshle@yandex.ru

Кулешов Сергей Михайлович - канд. ветеринар. наук, доц. каф. незаразных болезней, хирургии, акушерства Приморской государственной сельскохозяйственной академии, Приморский край, г. Уссурийск. E-mail: kyleshovsm@mail.ru

Куликов Евгений Владимирович - канд. биол. наук, доц. Департамента ветеринарной медицины Российского университета дружбы народов, г. Москва. E-mail: eugeny1978@list.ru

Кротова Елена Александровна - канд. ветеринар. наук, доц. Департамента ветеринарной медицины Российского университета дружбы народов, г. Москва. E-mail: elena_krotova_@mail.ru

Семенова Валентина Ивановна - канд. ветеринар. наук, доц. Департамента ветеринарной медицины Российского университета дружбы народов, г. Москва. E-mail: v_parshina@mail.ru

Цель исследования - изучить влияние микроструктуры различных режущих элементов в хирургии на регенерацию тканей. Данная проблема заключается в увеличении числа послеоперационных осложнений и случаев длительного заживления ран, а иногда переход остро-
Sakhno Nikolay Vladimirovich - Dr. Veterinary Sci., Prof., Chair of Epizootology and Therapy, Orel State Agrarian University named after N.V. Parakhin. Orel.

E-mail: sahnoorelsau@mail.ru

Vatnikov Yury Anatolyevich - Dr. Veterinary Sci., Prof., Director, Veterinary Medicine Department, Peoples' Friendship University of Russia, Moscow.

E-mail: vatnikov@yandex.ru

Shadskaya Anastasia Victorovna - Cand. Veterinary Sci., Assoc. Prof., Chair of Epizootology and Therapy, Orel State Agrarian University named after N. V. Parakhin. Orel.

E-mail: eshle@yandex.ru

Kuleshov Sergey Mikhaylovich - Cand. Veterinary Sci., Assoc. Prof., Chair of Noncontagious Diseases, Surgery, Obstetrics, Primorsk State Agricultural Academy, Primorsk Region, Ussuriysk.

E-mail: kyleshovsm@mail.ru

Kulikov Evgeny Vladimirovich - Cand. Biol. Sci., Assoc. Prof., Veterinary Medicine Department, Peoples' Friendship University of Russia, Moscow.

E-mail: eugeny1978@list.ru

Krotova Elena Alexandrovna - Cand. Veterinary Sci., Assoc. Prof., Veterinary Medicine Department, Peoples' Friendship University of Russia, Moscow.

E-mail: elena_krotova_@mail.ru

Semenova Valentina Ivanovna - Cand. Veterinary Sci., Assoc. Prof., Veterinary Medicine Department, Peoples' Friendship University of Russia, Moscow.

E-mail:v_parshina@mail.ru

го процесса в хронический, что свидетельствует о нерешенности вопросов послеоперационной регенерации поврежденных тканей. Для изучения регенераторных особенностей тканей выполнили разноплановые операции $(n=28)$ у телят, коз, собак. Помимо режущих инстру- 
ментов исследовали заостренную часть спии для чрескостного остеосинтеза, а также пилы при ампутации рогов, фетотомии у коров и коз. С использованием сканирующего электронного микроскопа Hitachi TM-1000 проведен анализ микроструктуры поверхности режущей части различных инструментов в низковакуумном режиме Standart Mode. При этом установлено, что во время выполнения разрезов лезвием из углеродистой стали отмечали незначительное затруднение при резании тканей из-за менее выраженного у него «эфрфекта пилы» в отличие от лезвия хирургического Stainless steel, но вместе с тем в процессе регенерации тканей после наложения швов наблюдали меньшее количество раневого отделяемого, чем при использовании лезвия Stainless steel. Исследования поверхности проволочной пилы показали, что при первом использовании на них недостаточно удалена заводская смазка, которая хорошо удерживает пыль, тем самым способствуя формированию обширного фрибринозно-лейкоцитарного струпа между краями операционной раны. В связи с чем механического снятия заводской смазки и обезжиривания этиловым спиртом не вполне достаточно. При микроскопии поверхности острия спиц Киршнера на отдельных участках изделий выявили поперечные деформации с зонами выдавливания сплава. После исследования спии, бывших в употреблении, отмечали значительнье нарушения в однородности их поверхности в виде поперечных трещин и изломов. По мнению авторов, формирование дефектов в структуре металлических фриксаторов не исключается в месте деформаций, образовавшихся при проведении остеосинтеза. Выявленные отличия между состоянием металлических фриксаторов до использования и после их извлечения из кости указывают на выраженную конфрликтность между имплантатом и биологическим объектом.

Ключевье слова: операция, хирургические инструменты, режущий элемент, микроструктура, разъединение тканей, раны, регенерация тканей.

The purpose of the research was to study the effect of the microstructure of various cutting elements in the surgery on tissue regeneration. The problem was in the increase of the number of postoperative complications and cases of prolonged wound healing, and sometimes the transition of an acute process to chronic, which indicates unresolved issues of postoperative regeneration of damaged tissues. In order to study regenerative features of tissues, diverse operations $(n=28)$ were performed in calves, goats, and dogs. In addition to cutting tools, the pointed part of the spokes for transosseous osteosynthesis, as well as the saws for amputation of horns, fetotomy in cows and goats, were investigated. Using a Hitachi TM-1000 scanning electron microscope, the microstructure of the surface of the cutting part of various tools was analyzed in the low vacuum Standart Mode. At the same time, it was found that during the cuts with a carbon steel blade, there was slight difficulty in cutting tissues due to "the saw effect" less pronounced for it, in contrast to surgical stainless steel blade, but at the same time, during tissue regeneration after suturing less wound was observed than when using a stainless steel blade. Wire saw surface examination showed that the first time it was used the factory grease was not sufficiently removed, retaining the dust, thereby contributing to the formation of an extensive fibrinous-leukocyte scab between the edges of surgical wound. In this connection mechanical removal of factory lubrication and degreasing with ethyl alcohol was not quite enough. The microscopy of the surface of the tip of Kirschner's knitting needles revealed transverse deformations with extrusion zones of the alloy in individual parts of the products. Used spokes examination showed significant disturbances in the uniformity of their surface in the form of transverse cracks and kinks. In the authors' opinion, the formation of defects in the structure of metal fixators was not excluded at the site of deformations formed during osteosynthesis. Revealed differences between the state of metal fixators before using and after their extraction from the bone indicated a pronounced conflict between the implant and biological object.

Keywords: operation, surgical instruments, cutting element, microstructure, tissue separation, wounds, tissue regeneration.

Введение. Хирургический метод имеет не только лечебный эфффект, но и выраженное разрушающее действие на ткани и органы, что само по себе может вызвать различные сдвиги 
в организме животного. Поэтому хирургу необходимо не только сохранить жизнь пациента, объективно оценить компенсаторные возможности больного организма, степень риска вмешательства, разработать мероприятия, устраняющие или снижающие опасность операции, но и определить рациональную хирургическую тактику, максимально сберечь фуннцию органов и тканей, подвергаемых операции. При этом следует учитывать анатомическую доступность, фризиологическую дозволенность, техническую возможность оперативного вмешательства [2].

Показания к разрезам в ветеринарной хирургии весьма разнообразны, поэтому различны и способы их выполнения. Однако во всех случаях необходимо соблюдать бережное отношение к тканям и органам, учитывать функциональное значение органа и его восстановительные способности. Разрезы не должны нарушать кровоснабжение и иннервацию тканей в оперируемой области, затруднять соединение краев раны швами, замедлять заживление ран и дальнейшую фуннкциональную нагрузку тканей. Величина, форма и направление разреза в каждом от- дельном случае зависят от анатомотопографических особенностей оперируемой области [3]. Поэтому оснащенность хирурга современными и, что самое главное, разнофункциональными и узкоспециализированными инструментами важна для успеха оперативного лечения животных.

Цель исследования. Изучить влияние микроструктуры различных режущих элементов в хирургии на регенерацию тканей.

Материалы и методы. На базе инновационного научно-исследовательского испытательного центра коллективного пользования Орловского ГАУ имени Н.В. Парахина с использованием сканирующего электронного микроскопа (СЭМ) Hitachi ТМ-1000 (рис. 1) проведен анализ микроструктуры поверхности режущей части различных инструментов в низковакуумном режиме Standart Mode. Расстояние между верхней частью исследуемого образца и верхней частью шахты под столик с образцом составило 1,0 мм. Перед исследованием образцов с них снимали заводскую смазку и обезжиривали этиловым ректификованным спиртом $96 \%[12,13]$.

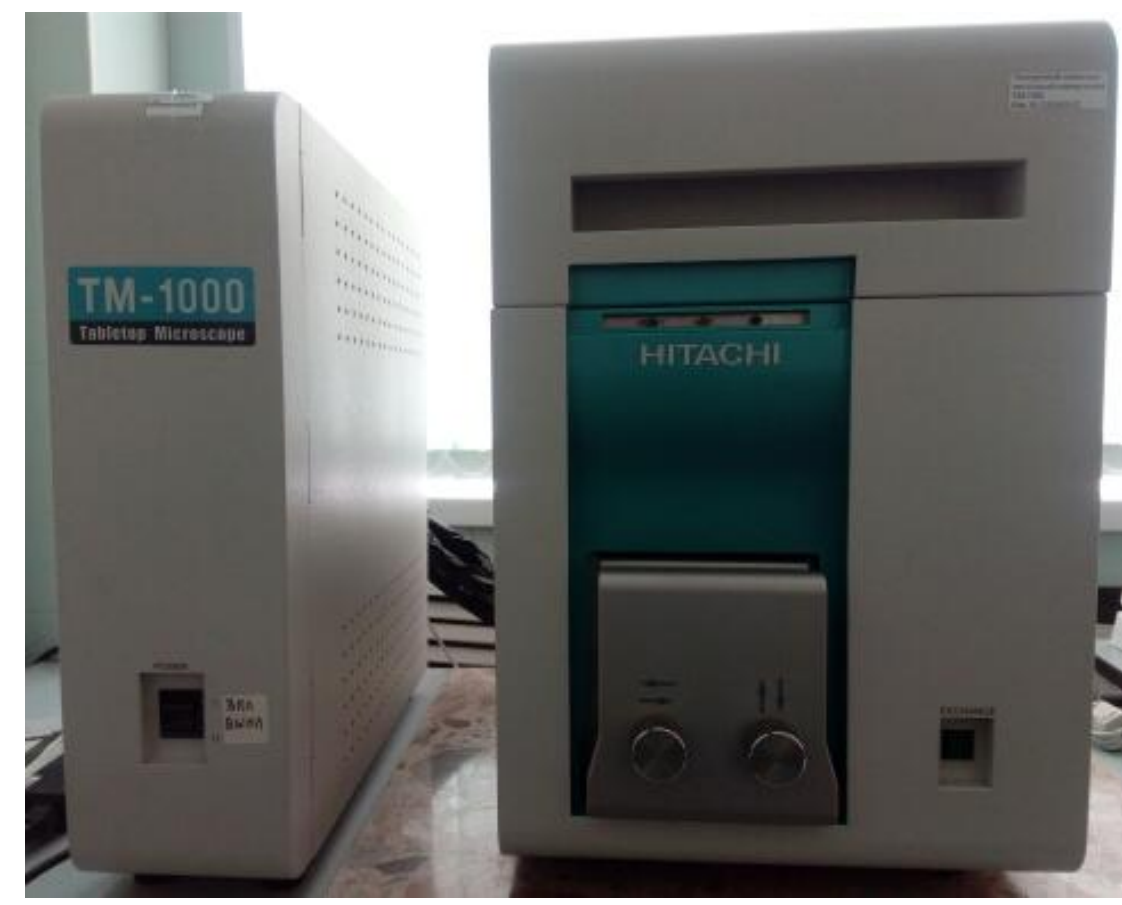

Puc. 1. Сканирующий электронный микроскоп модели TM-1000 фрирмы Hitachi Science Systems Ltd

Для изучения регенераторных особенностей тканей на базе ветеринарного лечебнодиагностического центра Орловского государственного аграрного университета имени Н.В. Па- рахина» и Департамента ветеринарной медицины Российского университета дружбы народов выполнили разноплановые операции $(n=28)$ у телят, коз (вскрытие абсцессов, ревизия и уши- 
вание ран), у собак (вскрытие абсцессов, удаление новообразований, овариогистероэктомия, остеосинтез) $[4,5,7,10]$. Помимо режущих инструментов исследовали заостренную часть спиц для чрескостного остеосинтеза, а также пилы (дуговые, листовые, проволочные при ампутации рогов, конечностей, проведении фетотомии у коров и коз).

Достоверность результатов относительно друг друга и относительно нормы оценивали по стандартному критерию Стьюдента. Значения $\mathrm{P}$ $<0,05$ считались значимыми. Все анализы были выполнены с использованием программного обеспечения SPSS для Windows версии 20.

Результаты исследований и их обсуждение. В последнее время широко используют скальпели со съемным лезвием для разъединения мягких тканей. Режущий элемент каждого из анализируемых лезвий (рис. 2-7) имеет небольшой угол заточки, предназначенный для резания мягких тканей. Известно, что оптимальные режущие свойства лезвия хирургического зависят также от микрогеометрии режущей кромки лезвия, ширина которой и высота ее микронеровностей должны быть от 2 до 5 мкм, при этом обеспечивается «эфффект пилы» [1, 3, 15].

Следует отметить, что у режущих элементов лезвий хирургических для мягких тканей угол заточки составляет от 12 до 25․, для рассечения хрящей - от 30 до $35^{\circ}$, и для разрезания костных тканей $-40^{\circ}$. При этом, чем меньше угол заострения, тем острее скальпель и тем быстрее он теряет остроту. Эффрект облегчения резания тканей наблюдается также при уменьшении угла наклона лезвия по отношению к разрезаемому материалу и замедлении скорости протягивания скальпеля. При проколе мягких тканей лезвие скальпеля должно располагаться под углом $90^{\circ}$ к поверхности ткани, а при выполнении их рассечения - под углом около $45^{\circ}$. Вместе с этим другим хирургическим инструментом, предназначенным для разъединения тканей или отделения их частей, являются ножницы, причем угол их заточки соответствует 70$85^{\circ}[1,3]$.

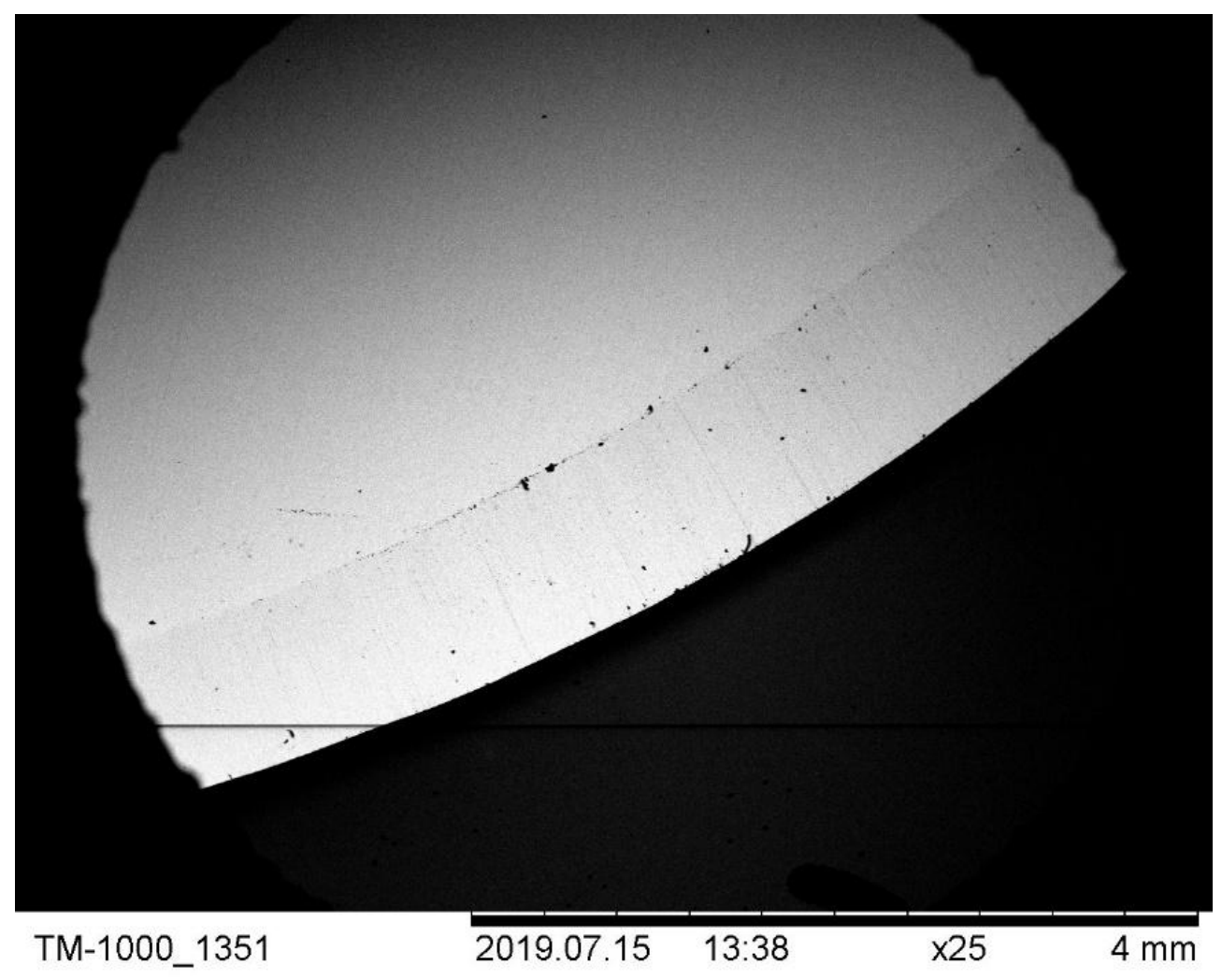

Puc. 2. Поверхность режущего элемента лезвия хирургического Stainless steel (ув. 25), СЭМ-изображение 


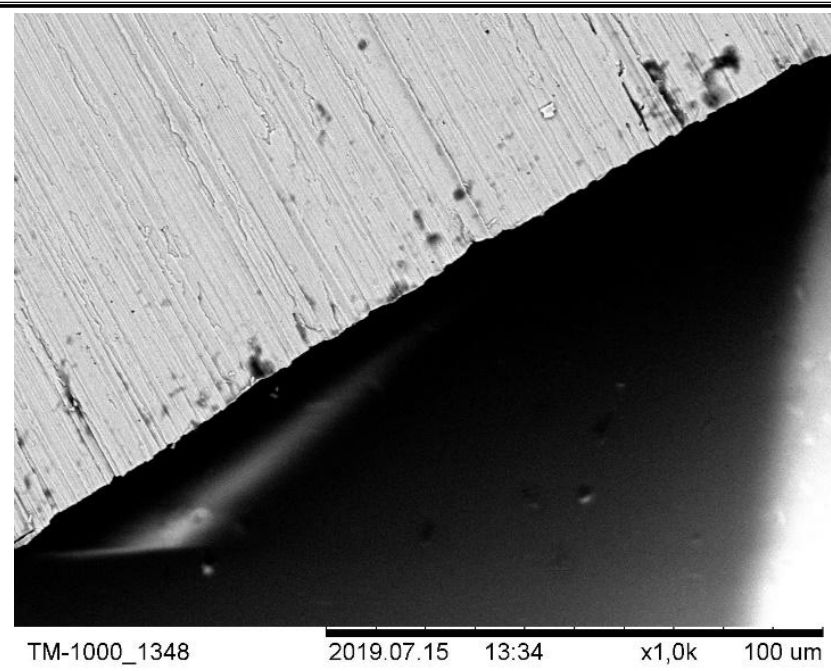

Puc. 3. Поверхность режущего элемента лезвия хирургического Stainless steel (ув. 1 000), СЭМ-изображение

При использовании тупых инструментов не только затрудняется работа хирурга, но и повышается риск нагноения операционной раны. В данном случае формируются микронекрозы ее краев вследствие увеличения размеров микронеровностей лезвия, которые приводят к образованию на краях раны значительных микроразрывов и микролоскутов, где нарушается трофрика тканей $[1,9,11]$.

При сканирующей электронной микроскопии поверхности режущего элемента лезвий хирургических двух разных моделей было выявлено заметное отличие в их заточке. Во время проведения операций и выполнения разрезов лезвием из углеродистой стали (рис. 4, 5 и 7) установлено незначительное затруднение при реза- нии тканей из-за менее выраженного у него «эффректа пилы» в отличие от лезвия хирургического Stainless steel (рис. 2, 3 и 6).

Однако в данном случае в процессе регенерации тканей после наложения швов наблюдали меньшее количество раневого отделяемого, чем при использовании лезвия Stainless steel. В целом уменьшение воспалительных процессов и заживление операционных ран происходило быстрее у животных (телят, коз, собак и кошек) после использования лезвия хирургического из углеродистой стали. Сроки заживления ран у этих животных наступали на 1,2 $\pm 0,04$ суток раньше, чем у животных после применения лезвия хирургического Stainless steel.

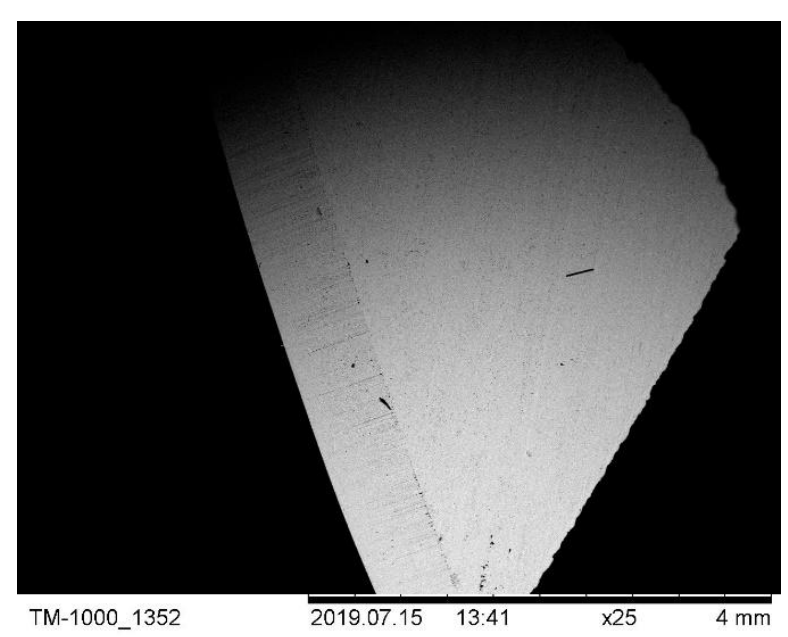

Puс. 4. Поверхность режущего элемента лезвия хирургического из углеродистой стали (ув. 25), СЭМ-изображение 


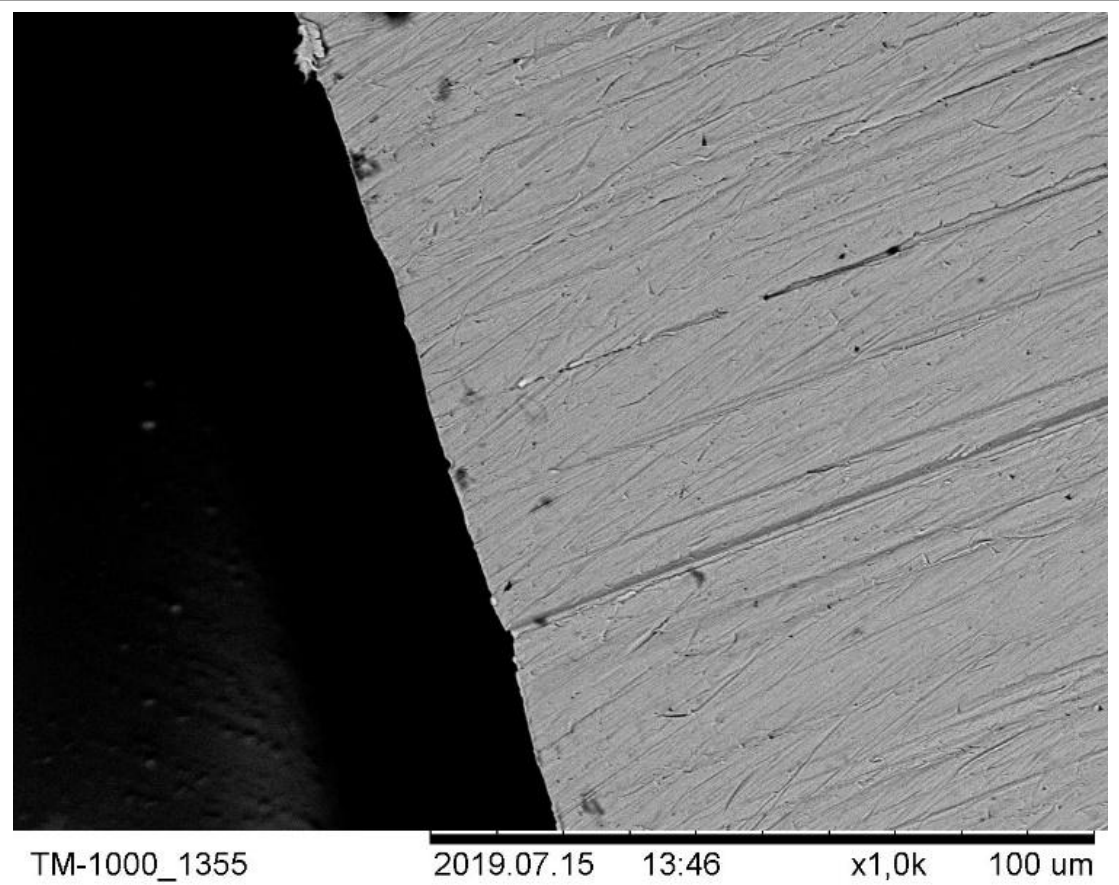

Puc. 5. Поверхность режущего элемента лезвия хирургического из углеродистой стали (ув. 1 000), СЭМ-изображение

Применение лезвия хирургического из углеродистой стали выявило уменьшение признаков воспаления с купированием воспалительного отека и переход раневого процесса из первой во вторую фазу заживления на 3-4-е сутки после оперативного вмешательства. В то время как при применении лезвия хирургического Stainless steel отек купировался к 4-5-м суткам после оперативного вмешательства. При этом срок появления грануляций в первом случае составлял у телят $2,1 \pm 0,13$ суток, у коз $2,3 \pm 0,11$, у собак $2,4 \pm 0,10$, у кошек - 2,0 $\pm 0,12$ суток, а после использования лезвия хирургического Stainless steel - соответственно: на $3,2 \pm 0,21 ; 3,4 \pm 0,18$; $3,6 \pm 0,28$ и 2,8 $\pm 0,14$ суток.

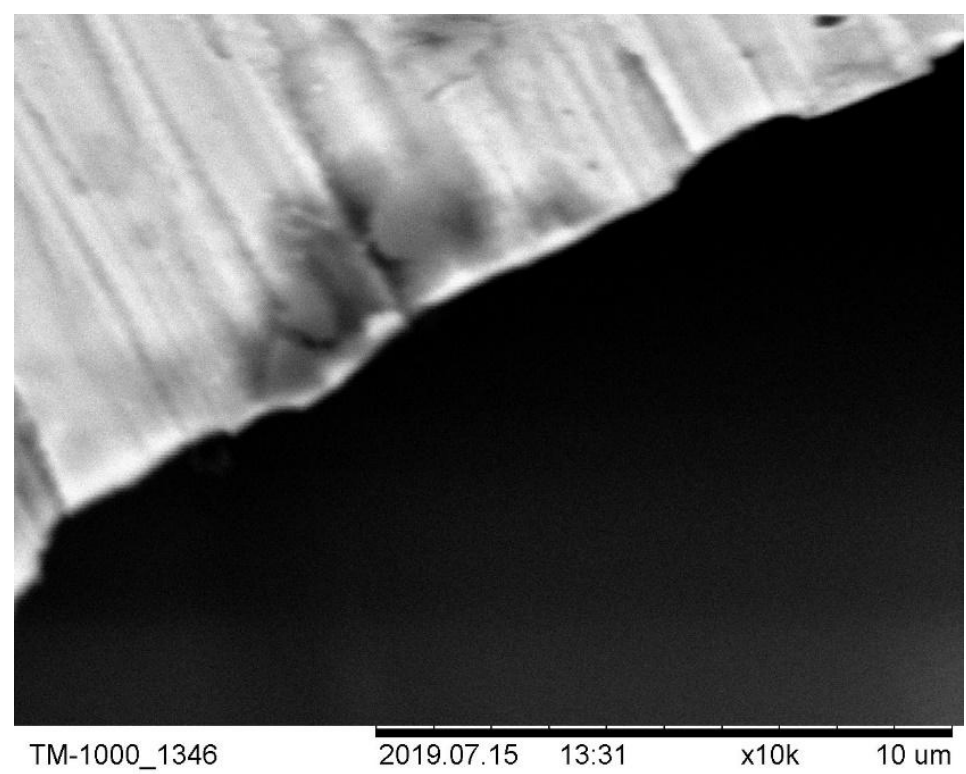

Puc. 6. Поверхность режущего элемента лезвия хирургического Stainless steel (ув. 10 000), СЭМ-изображение 


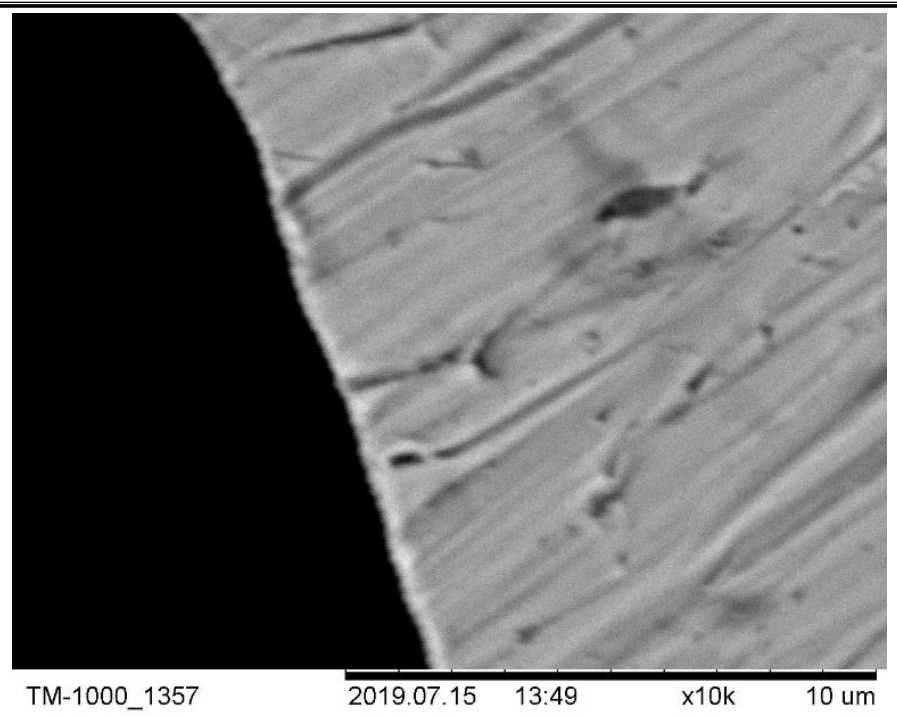

Puс. 7. Поверхность режущего элемента лезвия хирургического из углеродистой стали (ув. 10 000), СЭМ-изображение

В целом, независимо от сроков регенерации тканей у животных разных групп, наблюдали благоприятное течение раневого процесса и заживление травмированных тканей по первичному натяжению. Раны заживали без признаков инфильтрации, в отделяемом ран было небольшое количество секрета. Формировался нежный, легко смещаемый, негипертрофический кожный рубец.

К инструментам для разъединения тканей относят также пилы (дуговые, листовые, проволочные), а для прокалывания тканей применяют хирургические иглы и спицы для чрескостного остеосинтеза. Последние используются при проведении операций на костях [3]. В этой связи был проведен также анализ микроструктуры поверхности проволочных пил (рис. 8-13), которые используют для ампутации, например дистальных отделов конечностей с прерыванием кости по длине (поперечная остеотомия). Для перепиливания кости часто используют проволочную пилу Оливекрона с держателями Джигли.

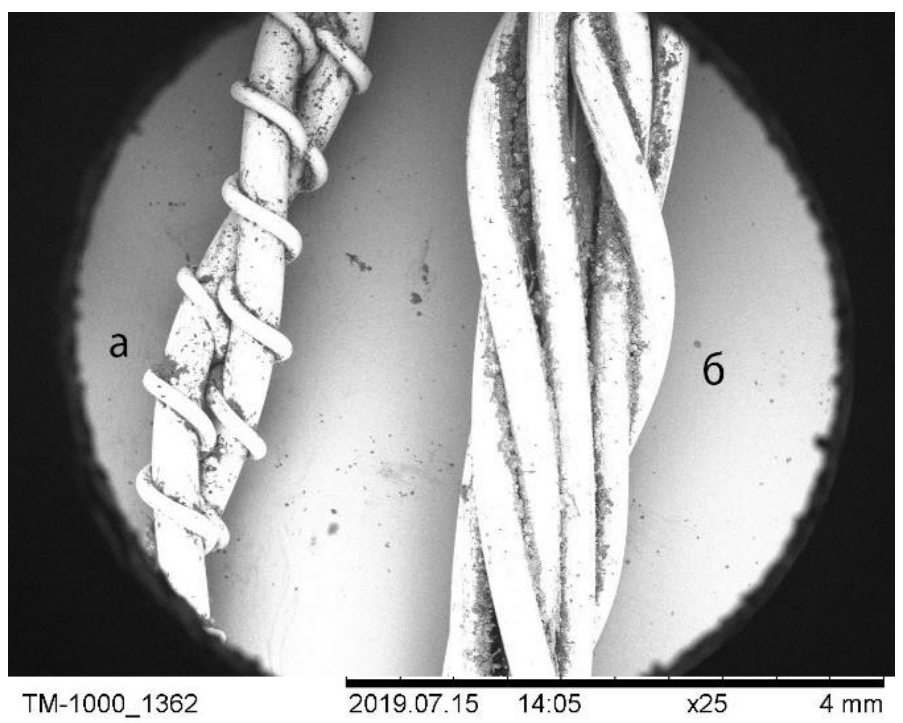

Puc. 8. Поверхность проволочной пилы Оливекрона (а) и проволочной пилы для фетотомии (б) (ув. 25), СЭМ-изображение 


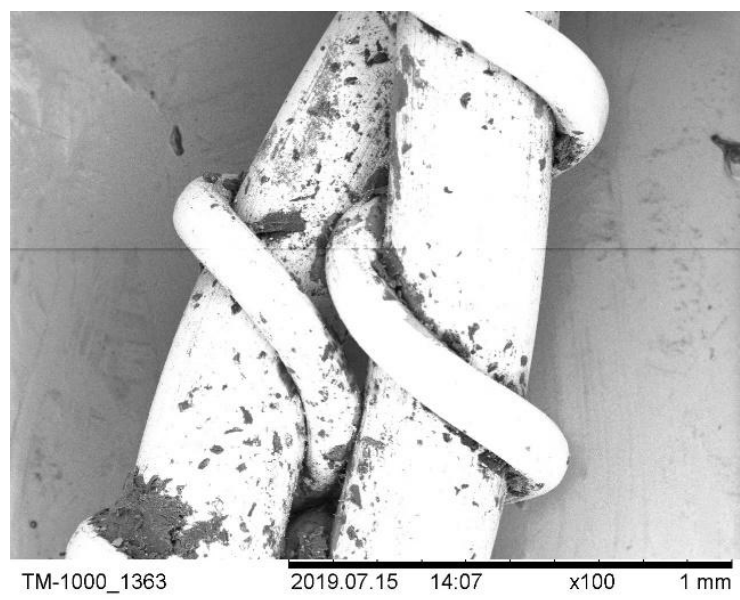

Puс. 9. Поверхность проволочной пилы Оливекрона (ув. 100), СЭМ-изображение

Анализ поверхности пил разных конструкций, них недостаточно удалена заводская смазка, представленных на микрофотографиях при раз- которая хорошо удерживает пыль.

личном фокусном расстоянии показал, что на

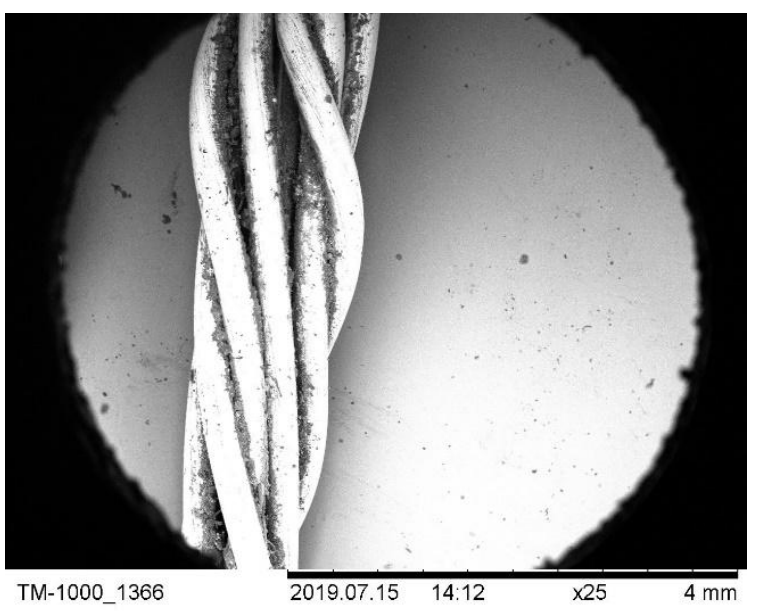

Puс. 10. Поверхность проволочной пилы для фретотомии (ув. 25), СЭМ-изображение

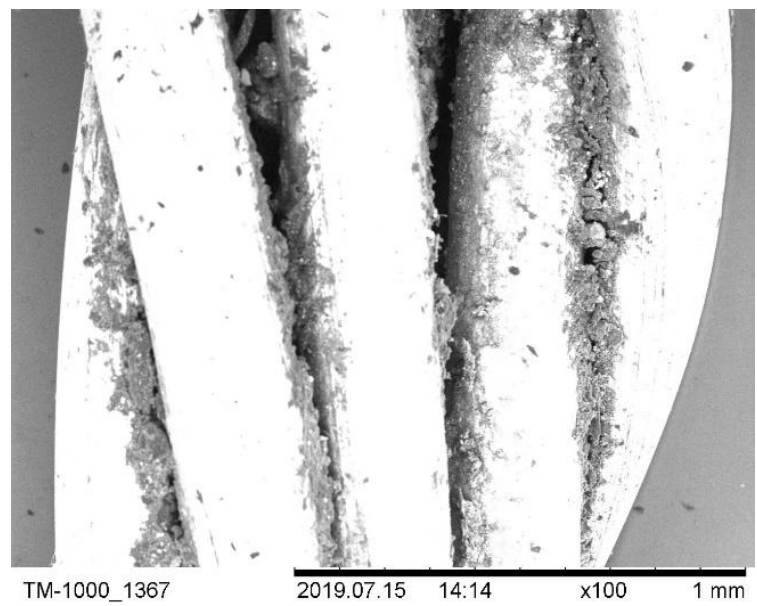

Puc. 11. Поверхность проволочной пилы для фетотомии (ув. 100), СЭМ-изображение 
Возможно, в том числе и поэтому (а не только из-за обширности травмы при ампутациях) после применения пил для остеотомии у животных формировался обширный фибринозно-лейкоцитарный струп между краями операционных ран. При этом расстояние между сопоставленными краями ран составило у собак $0,6-1,1 \mathrm{~cm}$, а у кошек в пределах 0,5 см. Применение пил провоцировало заживление ран вторичным натяжением у большинства животных.

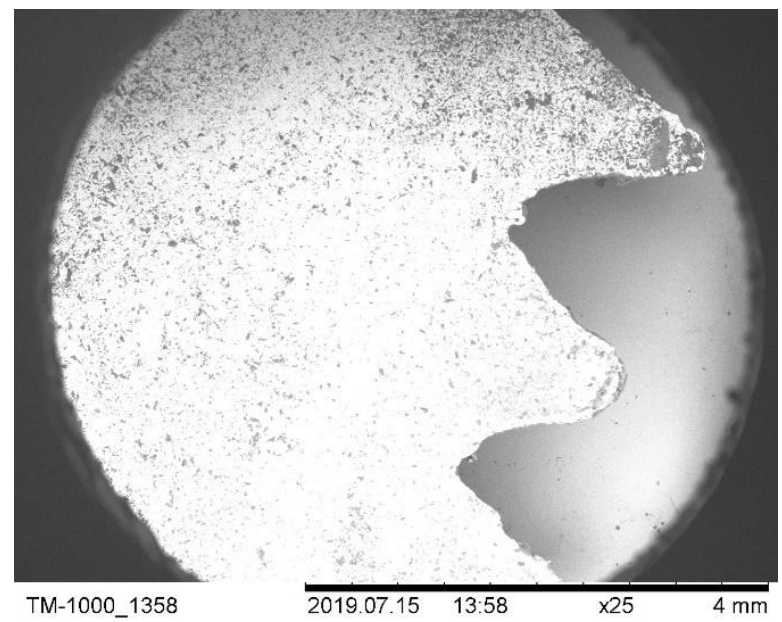

Puc. 12. Поверхность режущего элемента пилы дуговой для остеотомии (ув. 25), СЭМ-изображение

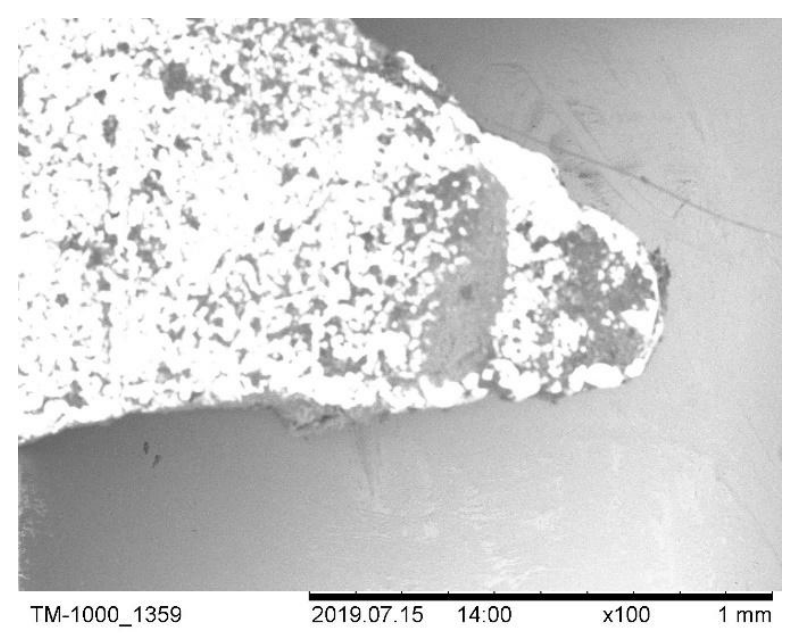

Puс. 13. Поверхность режущего элемента пилы дуговой для остеотомии (ув. 100), СЭМ-изображение

Очевидно, что механическое снятие заводской смазки и обезжиривание этиловым ректификованным спиртом 96 \% проволочных пил и режущей части пилы дуговой для остеотомии является не вполне достаточным. Для обезжиривания заводских изделий перед их использованием в хирургии (за исключением стерильных в индивидуальных упаковках) рационально проводить кипячение с последующей промывкой с одним из моющих средств в теплой воде. После этого следует дополнительно проводить обезжиривание этиловым ректификованным спиртом $96 \%$. Непосредственно перед применением, например, спиц проводят их дезинфекцию в автоклаве или сухожаровом шкафу.

При проведении чрескостной иммобилизации отломков костей с применением аппаратов для внешней фиксации для прокалывания мягких тканей используют спицы. Сначала прокалывают слои мягких тканей до упора конца спицы в 
кость, а после прохождения спицы через кость и выхождения ее конца из мягких тканей последние около него натягиваются и их прижимают инструментом с отверстием для прохождения спицы [8]. Следует помнить, что при вращении спицы выделяется большое количество тепла, поэтому во избежание образования кольцевых некрозов с их последующим секвестрированием применяют электродрель с малым числом оборотов $[11,14]$.
При сканирующей электронной микроскопии поверхности острия спиц Киршнера после снятия заводской смазки в целом установлена однородность структуры (рис. 14-17). На отдельных участках изделий выявлены поперечные деформации длиною от 2,2 до 3,8 uт с зонами выдавливания сплава. Этому могли способствовать десекты в форме для изделия или нарушение технологии его изготовления.

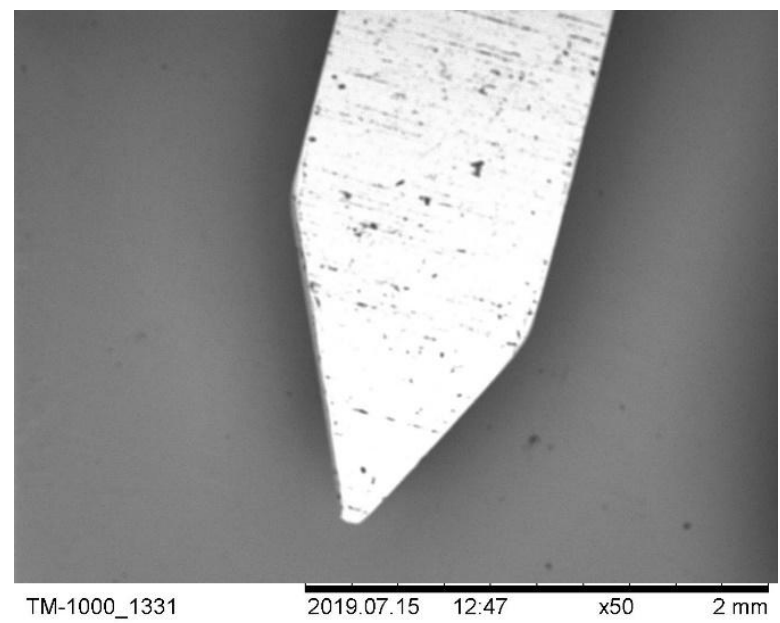

Puс. 14. Поверхность спицы Киршнера с перовидной заточкой (ув. 50), СЭМ-изображение

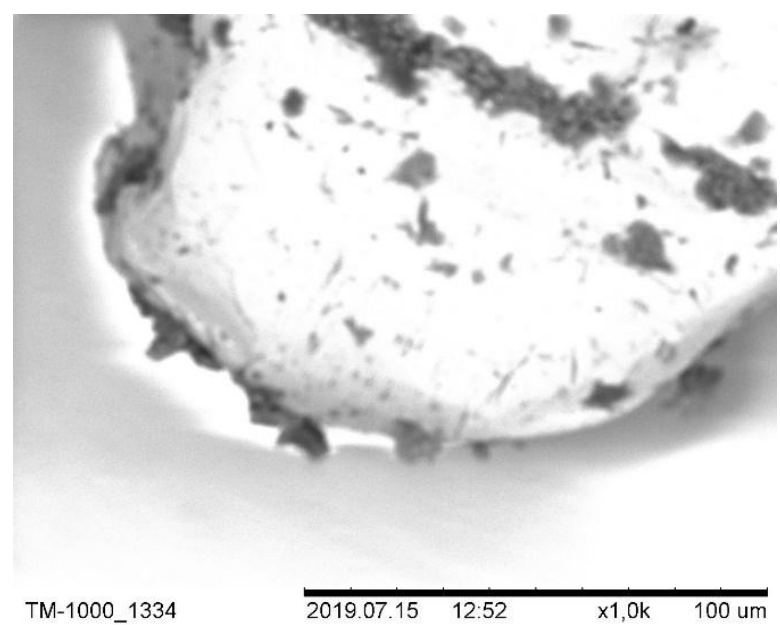

Puс. 15. Поверхность спицы Киршнера с перовидной заточкой (ув. 1 000), СЭМ-изображение

Например, выявлены зоны (поры), не заполненные металлом, диаметром от 0,10 um до десектов размером 0,62x1,07 um. Не исключено, что это места, занятые пузырьками воздуха при формовке изделия, снижающие в дальней- шем инертность этого фиксатора. Представленная картина предполагает более высокие требования к изготовлению металлических изделий для остеосинтеза, именуемых малоконфрликтными или даже инертными к тканям. 


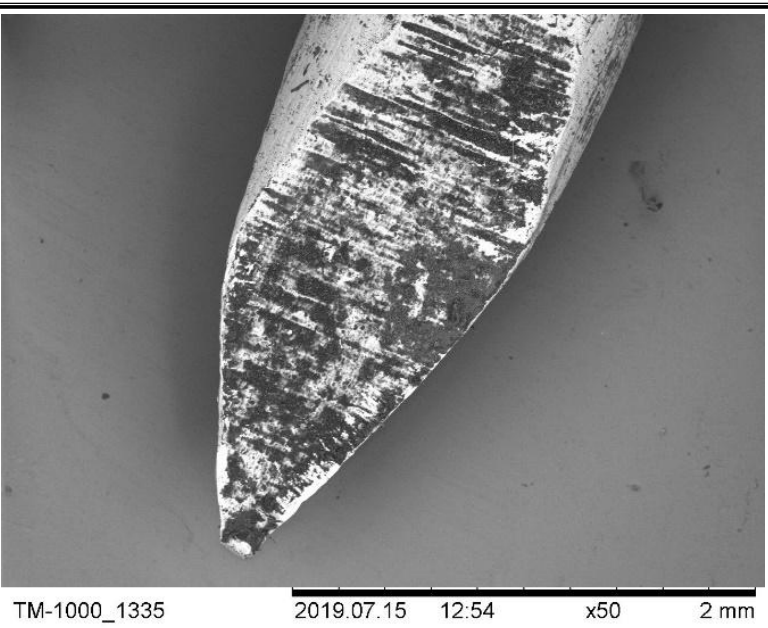

Pис. 16. Поверхность спицы Киршнера с копьевидной заточкой (ув. 50), СЭМ-изображение

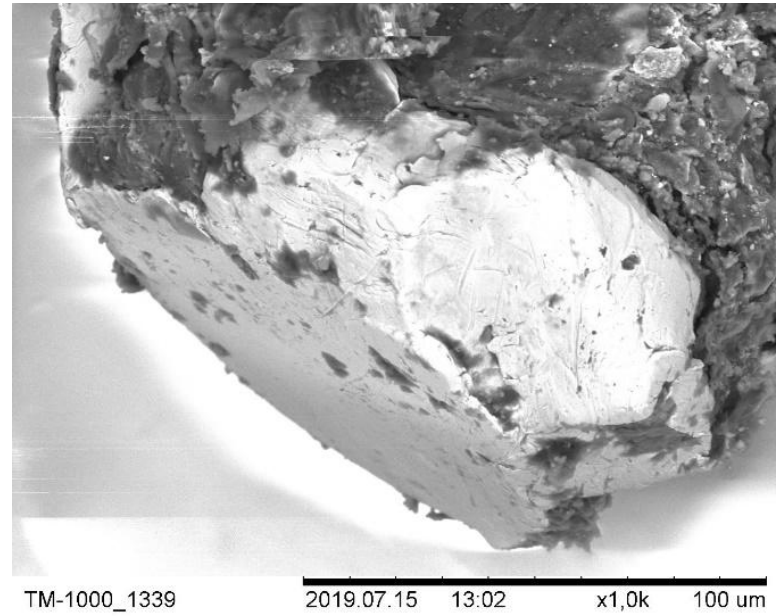

Puс. 17. Поверхность спищы Киршнера с копьевидной заточкой (ув. 1 000), СЭМ-изображение

По завершении консолидации отломков на 45-60-е сутки после остеосинтеза спицы Киршнера удаляют из травмированной кости. Как показала практика, после исследования спиц, бывших в употреблении, выявляют значительные нарушения в однородности их поверхности. Так, были обнаружены поперечные трещины и изломы длиною до 16,40 uт и шириною до 6,80 um. Отмеченные нарушения в структуре спиц Киршнера формировались из уже имеющихся после их изготовления дефектов, и кратность их увеличения после эксплуатации спиц Киршнера составила 6,8-16,4 раза [5, 6, 12, 13].

Формирование десектов в структуре металлических фиксаторов не исключается в месте десормаций, образовавшихся при проведении остеосинтеза. Факторами, предрасполагающими к изменению структурного состояния поверхно- сти металлических фриксаторов, являются: удержание фриксатора в ходе операции металлическими инструментами (необходимо оснащение рабочей части их захватов покрытием из твердой резины); продвижение спицы в костномозговой канал посредством ударов молотка для остеосинтеза, провоцирующее деформацию спицы относительно продольной оси и сплющивание ее заостренного конца; принятие анатомической кривизны кости дисконгруэнтным имплантатом. Не менее значимым в нарушении структуры поверхности металлических имплантатов является продвижение фиксатора через толщу одного из эпифизов травмированной кости, не исключающее образование продольных микроцарапин, которые бывают спиральными при вращении спицы, продвигаемой в просвет трубчатой кости при помощи дрели. 
Выявленные отличия между состоянием металлических фиксаторов до использования и после их извлечения из кости указывают на выраженную конфликтность между имплантатом и биологическим объектом.

Выводы. С целью снижения частоты и величины образования некрозов краев раны целесообразно использование лезвий с микронеровностями на режущей кромке высотой не более 5 мкм и ее шириной не более 5 мкм. Во избежание механических повреждений поверхности проволочных и дуговых пил, металлических спиц для остеосинтеза необходимы индивидуальные упаковки для их транспортировки и хранения. Кроме того, исключение повторного использования лезвий хирургических, проволочных пил, режущей части пилы дуговой для остеотомии, спиц для чрескостного остеосинтеза профилактирует развитие относительно крупных послеоперационных некротических изменений в области резания и способствует более качественному асептическому состоянию операционных ран и их заживлению по первичному натяжению с минимальной зоной травматизации тканей.

\section{Литература}

1. Большаков О.П., Семенов Г.М. Лекции по оперативной хирургии и клинической анатомии. СПб.: Питер, 2000. С. 69-195.

2. Иванова В.Д. Избранные лекции по оперативной хирургии и клинической анатомии. Самара: СамГМУ; СМИ «Реавиз», 2000. C. 5-7.

3. Инструменты и оборудование в ветеринарной хирургии. История и современность: учеб. пособие / Н.В. Сахно, Ю.А. Ватников, С.А. Ягников [и др.]; под общ. ред. Н.В. Сахно. СПб.: Лань, 2017. 152 с.

4. Методология обучения ветеринарной хирургии: учеб. пособие / Н.В. Сахно, Ю.А. Ватников, С.А. Ягников [и др.]. СПб.: Лань, 2020. $184 \mathrm{C}$.

5. Сахно H.B., Тимосреев С.В., Черванев В.А. Лечение переломов трубчатых костей у животных: учеб. пособие. СПб.: Лань, 2007. $192 \mathrm{c}$.

6. Сахно Н.В. Наноструктурные изменения металлических фиксаторов и костной ткани после остеосинтеза // Актуальные проблемы ветеринарной хирургии: мат-лы междунар. науч. конф. Ульяновск, 2011. С. 259269.

7. Сахно Н.В., Ватников Ю.А., Прудченко Т.А. Модифицированный ранорасширитель // Мат-лы VII Всерос. межвуз. конф. по ветеринарной хирургии. М., 2017. С. 164-171.

8. Сахно Н.В. Определение оптимального способа остеосинтеза у собак при косых переломах // Аграрная наука. 2009. № 6. C. 35-36.

9. Сахно Н.B. Оптимизация репаративного остеогенеза при костных травмах у мелких домашних животных: дис. ... д-ра ветеринар. наук. М., 2012. 375 C.

10. Сахно Н.В., Ватников Ю.А., Шадская А.В. Сравнительный анализ структуры хирургического шовного материала // Теоретические и прикладные проблемы агропромышленного комплекса. 2019. № 4 (42). С. 5864.

11. Сергиенко В.И., Петросян Э.А., Фраучи И.B. Топографическая анатомия и оперативная хирургия / под ред. Ю.М. Лопухина. М.: ГЭОТАР-МЕД, 2001. С. 30-52.

12. Электронная микроскопия в биологии и ветеринарии: учеб. пособие / Н.В. Сахно, В.С. Буяров, Ю.А. Ватников [и др.]; под. ред. Н.В. Сахно. Орел: Изд.-во ФГБОУ ВО Орловский ГАУ, 2015. 128 с.

13. Электронная микроскопия в клинической ветеринарии: учеб. пособие / Н.В. Сахно, Ю.А. Ватников, Е.М. Ленченко [и др.]. СПб.: Лань, 2020. 188 с.

14. Liao S., Li B., Ma Z., Wei H., Chan C., Ramakrishna $S$. Biomimetic electrospun nanofibers for tissue regeneration // Biomed. Mater. (Bristol, England), 1 (3) (2006), P. R45-R53

15. Shoulders M.D., Raines R.T. Collagen structure and stability/l Annu. Rev. Biochem. 78 (2009), P. 929-958.

\section{Literatura}

1. Bol'shakov O.P., Semenov G.M. Lekcii po operativnoj hirurgii i klinicheskoj anatomii. SPb.: Piter, 2000. S. 69-195. 
2. Ivanova V.D. Izbrannye lekcii po operativnoj hirurgii i klinicheskoj anatomii. Samara: SamGMU; SMI «Reaviz», 2000. S. 5-7.

3. Instrumenty i oborudovanie $\mathrm{V}$ veterinarnoj hirurgii. Istorija i sovremennost': ucheb. posobie / N.V. Sahno, Ju.A. Vatnikov, S.A. Jagnikov [i dr.]; pod obshh. red. N.V. Sahno. SPb.: Lan', 2017. 152 s.

4. Metodologija obuchenija veterinarnoj hirurgii: ucheb. posobie / N.V. Sahno, Ju.A. Vatnikov, S.A. Jagnikov [i dr.]. SPb.: Lan', 2020. 184 s.

5. Sahno N.V., Timofeev S.V., Chervanev V.A. Lechenie perelomov trubchatyh kostej $u$ zhivotnyh: ucheb. posobie. SPb.: Lan', 2007. $192 \mathrm{~s}$.

6. Sahno N.V. Nanostrukturnye izmenenija metallicheskih fiksatorov i kostnoj tkani posle osteosinteza I/ Aktual'nye problemy veterinarnoj hirurgii: mat-ly mezhdunar. nauch. konf. Ul'janovsk, 2011. S. 259-269.

7. Sahno N.V., Vatnikov Ju.A., Prudchenko T.A. Modificirovannyj ranorasshiritel' // Mat-ly VII Vseros. mezhvuz. konf. po veterinarnoj hirurgii. M., 2017. S. 164-171.

8. Sahno N.V. Opredelenie optimal'nogo sposoba osteosinteza u sobak pri kosyh perelomah // Agrarnaja nauka. 2009. № 6. S. 35-36.
9. Sahno N.V. Optimizacija reparativnogo osteogeneza pri kostnyh travmah u melkih domashnih zhivotnyh: dis. ... d-ra veterinar. nauk. M., 2012. $375 \mathrm{~s}$.

10. Sahno N.V., Vatnikov Ju.A., Shadskaja A.V. Sravnitel'nyj analiz struktury hirurgicheskogo shovnogo materiala // Teoreticheskie i prikladnye problemy agropromyshlennogo kompleksa. 2019. № 4 (42). S. 58-64.

11. Sergienko V.I., Petrosjan Je.A., Frauchi I.V. Topograficheskaja anatomija i operativnaja hirurgija / pod red. Ju.M. Lopuhina. M.: GJeOTAR-MED, 2001. S. 30-52.

12. Jelektronnaja mikroskopija $\mathrm{V}$ biologii $\mathrm{i}$ veterinarii: ucheb. posobie / N.V. Sahno, V.S. Bujarov, Ju.A. Vatnikov [i dr.]; pod. red. N.V. Sahno. Orel: Izd.-vo FGBOU VO Orlovskij GAU, 2015. $128 \mathrm{~s}$.

13. Jelektronnaja mikroskopija $\mathrm{v}$ klinicheskoj veterinarii: ucheb. posobie / N.V. Sahno, Ju.A. Vatnikov, E.M. Lenchenko [i dr.]. SPb.: Lan', 2020. $188 \mathrm{~s}$.

14. Liao S., Li B., Ma Z., Wei H., Chan C., Ramakrishna $S$. Biomimetic electrospun nanofibers for tissue regeneration // Biomed. Mater. (Bristol, England), 1 (3) (2006), P. R45-R53.

15. Shoulders M.D., Raines R.T. Collagen structure and stability/l Annu. Rev. Biochem. 78 (2009), P. 929-958. 